\title{
LuCYNA SADZiKowsKa
}

(D) https://orcid.org/0000-0002-5509-4513

Instytut Literaturoznawstwa, Uniwersytet Śląski

\section{Sama czeluść}

\author{
Wiem, jak wyglada piekło. Alina Dąbrowska w rozmowie \\ $z$ Wiktorem Krajewskim. Warszawa, Prószyński i S-ka, 2019, ss. 368.
}

\author{
Tenderness Alone
}

Abstract: The text discusses an interview conducted by Wiktor Krajewski with Alina Dąbrowska, one of the last living witnesses of history, a prisoner of five concentration camps, forced to participate in two Death Marches. While discussing her most difficult experiences during the Second World War, Dąbrowska attempts to assess the human relations. By divulging and explaining what influenced her life choices, how she perceives the infernal life of concentration camp and how she sees herself, she reveals her ethical investment in narrating her own life story.

Czytając historię życia Aliny Dąbrowskiej, można się - dosłownie - załamać. Bohaterka recenzowanej książki twierdzi jednak, że nie ma sytuacji bez wyjścia, a każde szaleństwo ma swój początek i koniec. „Dałam sama sobie kredyt zaufania i przyrzekłam, że zrobię wszystko, aby wytrzymać niekończącą się opresję i nienawiść ze strony Niemców. Bo piekło musi mieć kres. Piekło nie może trwać wiecznie" (s. 162). Wojna, pobyt w więzieniu i zniewolenie w obozach koncentracyjnych nie przeszkodziły jej w tym, by widziała życie w jasnych kolorach. Zawsze istnieje nadzieja, że los może się odmienić. I ta nauka po lekturze Wiem, jak wygląda piekło... powinna towarzyszyć czytelnikowi w życiu codziennym.

Alina Dąbrowska, rocznik 1923, ma biografię niczym epos. To bogaty życiorys wypełniony licznymi dramatycznymi i ciekawymi wydarzeniami, których była uczestnikiem bądź świadkiem.

Małą ojczyzną Dąbrowskiej były Pabianice. Tam przyszła na świat w rodzinie, która zaszczepiła w niej ducha patriotyzmu oraz przywiązanie do wartości 
rodzinnych. Tam wzrastała wśród Żydów, Niemców i Polaków. Świat dzieciństwa i lata dziewczęce, a nade wszystko rodzice - Anna z domu Gertner i Konstanty Bartoszek - mieli wielki wpływ na ukształtowanie osobowości i mentalności rozmówczyni Wiktora Krajewskiego. Jako dziewczynka była ruchliwa, mówi się - żywe srebro. Zresztą do dzisiaj Alina Dąbrowska posiada talent zjednywania sobie ludzi, tryska energią, witalnością, a droga, którą musiała w życiu przejść, nie robi na niej większego wrażenia. Ma się nieodparte odczucie, że pozostało w niej coś z dziecka, albowiem nawet „o traumie opowiada $\mathrm{z}$ delikatnie przymrużonymi oczami lub patrząc gdzieś przed siebie z tajemniczym uśmiechem, który często można zauważyć na twarzy małej dziewczynki, liczącej na to, że jej wybryki i psoty nigdy nie zostaną odkryte przez rodziców i ujdą jej na sucho" (s. 15-16)1.

Uwielbiała szkołę, przez całe życie, nawet w lagrze ${ }^{2}$ i za więziennym ogrodzeniem, jedną z najważniejszych spraw była dla niej nauka, zwłaszcza języków obcych. Przed wybuchem wojny, w związku z chęcią zaopiekowania się dziewczynką, która znajdowała się pod kuratelą ciotki, Alina Dąbrowska zaczęła uczyć się języka niemieckiego. Jak sama podkreśla, był to moment, który zaważył na jej dalszym więzienno-obozowym życiu, szczęśliwy traf losu, przeznaczenie czy może lepiej napisać - zgodnie z oceną sytuacji przez samą zainteresowaną opatrzność Boża. Błahy wybór, jakim było podjęcie nauki języka niemieckiego, najprawdopodobniej pośrednio wielokrotnie uratował życie Dąbrowskiej.

Wydawać by się mogło, że wojna przekreśliła jej plany, marzenia i przyszłość, ale bohaterka Wiem, jak wyglada piekło... twierdzi, że doświadczenie wojenno-obozowe ukształtowało ją, zdeterminowało jej dalsze - dorosłe - życie, to, kim i jaka była. W jakimś sensie to, co przeżyła, wzbogaciło ją.

Alina Dąbrowska ${ }^{3}$, z którą pod koniec lutego 2017 roku przeprowadziłam trwający ponad dwie godziny wywiad w jej warszawskim domu, była więźniem pięciu obozów koncentracyjnych: KL Auschwitz-Birkenau (numer obozowy 44165), KL Ravensbrück (przewieziona 23 stycznia 1945 roku), KL Malchow (przewieziona w lutym 1945 roku), KL Buchenwald (przewieziona w marcu 1945 roku), KL Leipzig (przewieziona w kwietniu 1945 roku). Uczestniczyła w dwóch

${ }^{1}$ Spostrzeżenia i obserwacje poczynione przez Wiktora Krajewskiego nie są mi obce i wynikają również z mojego doświadczenia jako rozmówczyni oraz autorki wywiadu z Aliną Dąbrowską opublikowanego w „Narracjach o Zagładzie” w 2017 r. Por. „Oni szli do lasu, po prostu do lasu...". Zagłada Żydów w KL Auschwitz-Birkenau we wspomnieniach Aliny Dąbrowskiej. Oprac. L. Sadzikowska. „Narracje o Zagładzie” 2017, nr 3, s. 366-373.

${ }^{2}$ W książce pojawia się, np. na stronach 274, 275, 289, błędny zapis.

${ }^{3}$ Po wojnie ukończyła wieczorowo Akademię Nauk Politycznych w Warszawie, a w 1947 r. podjęła pracę w Ministerstwie Spraw Zagranicznych, gdzie poznała przyszłego męża - Bogumiła. Zwiedziła 27 krajów. Ma dwie córki: Jagnę i Magdalenę, która przyszła na świat w Chinach, gdzie jej rodzice pracowali w placówce dyplomatycznej. Pod koniec lat 60. cała rodzina Dąbrowskich wyjechała do Budapesztu. Tam Bogumił Dąbrowski objął stanowisko zastępcy ambasadora na Węgrzech. Alina Dąbrowska doczekała się wnuków. Największymi wartościami w jej życiu są rodzina i dom, który udało się jej stworzyć. 
Marszach Śmierci. W pierwszym z wymienionych obozów, do którego to miejsca nie wróciła przez pięćdziesiąt lat, gdyż nie mogła się przełamać, była poddawana pseudomedycznym eksperymentom doktora Josefa Mengele.

Doznała, działając w Szarych Szeregach, goryczy unicestwiania niepodległej Polski. Dla jej pokolenia - choć dla innych, wyrosłych w niezwykłej atmosferze patriotycznej, także - był to wyjątkowy wstrząs. Kto mógł uwierzyć, że Polska może upaść ponownie? Alina Dąbrowska, nim się spostrzegła, licząc zaledwie dwadzieścia lat, za druk i kolportowanie prasy podziemnej trafiła w ręce niemieckich okupantów. Po roku podpisała dokument, że jest „wrogiem narodu niemieckiego”, i trafiła do jednego z najcięższych hitlerowskich kacetów - do Auschwitz.

$\mathrm{Z}$ właściwym sobie dystansem i namysłem Dąbrowska wspomina o zniewoleniu obozowym, o swoich licznych więziennych i lagrowych poniewierkach, podkreślając jednocześnie, że docenia wszelkie szczęśliwe chwile, które przeżyła, kiedy wokół na dobre rozgościły się nieszczęście, wojna i terror. Choćby tak:

Nie widzę powodów, aby skupiać się tylko na okrucieństwie, które tam widziałam. Niektóre osoby mają skłonność do tego, żeby wspominając wojenną rzeczywistość, przywoływać tylko negatywne odczucia i traumę, którą przeszliśmy. Rzeczywiście, te doświadczenia są straszne, ale mam je już za sobą. Życie nie polega na rozpamiętywaniu wyłącznie przeszłości. Trzeba o niej pamiętać, wyciągać wnioski z tego, co przeżyliśmy, czego się nauczyliśmy, ale musimy zdawać sobie przy tym wszystkim sprawę, że należy obserwować to, co dzieje się tu i teraz. Bo później możemy żałować, że przegapiliśmy wiele fantastycznych momentów. Ktoś mógłby przecież pomyśleć, że ja miałam wielkiego pecha i spotkało mnie wiele nieszczęścia w bardzo młodym wieku. Ciężka sytuacja rodzinna, choroba mamy, aresztowanie, obozy... Wygląda to na prawdziwy dramat. Tylko w tym dramacie było naprawdę dużo szczęścia i właśnie te chwile są warte wspominania.

Matka Aliny Dąbrowskiej udzielała schronienia Żydom. Alina była świadkiem, kiedy wynosiła $\mathrm{z}$ mieszkania dla ukrywających się na strychu talerz $\mathrm{z}$ jedzeniem. Widziała też agonię i unicestwianie rodzinnego miasta, dziesiątki ofiar, a wśród nich swoich kolegów i koleżanki.

Rozmowa Wiktora Krajewskiego ${ }^{4}$ z Aliną Dąbrowską wpisuje się we współczesne trendy tworzenia tzw. historii mówionej i historii życia, „na którą składają się nie polityczne traktaty i wielkie bitwy, ale przede wszystkim losy ludzi, rodzin, dzieci - opis tego, co przeżywali mając za sobą tło wydarzeń światowych" ${ }^{\text {. Wy- }}$

${ }^{4}$ Wiem, jak wygląda piekło... to trzecia książka Wiktora Krajewskiego. Zadebiutował w 2015 r., wydając razem z Marią Fredro-Boniecką Łączniczki. Wspomnienia z Powstania Warszawskiego. Kolejną pozycją były Pocztówki z powstania. Bohaterką pierwszej książki była babcia autora. W ten sposób chciał upamiętnić jej działalność podczas wojny.

${ }^{5}$ D. Kondratiuk: Przedmowa. W: Henryk Perkowski. Przeżyć każdy dzień. Wspomnienia obozowe 1944-1945. Red. nauk. P. Sobieszczak. Łapy 2014, s. V. 
wiad z Dąbrowską może stanowić interesujący materiał zarówno dla studiów nad ludobójstwami, jak i pamięcią czy traumą, świadomie bowiem prowokuje polemiczny namysł, dowodząc, że siła wojenno-obozowego doświadczenia powinna być rozpatrywana tylko przez pryzmat jednostkowych afektywnych zapisów ${ }^{6}$.

Warto podkreślić, że Dąbrowska nie godzi się na niesprawiedliwość i brak odpowiedzialności. Po kilkudziesięciu latach dojrzała, by eksplorować i odsłaniać swoją pamięć prywatną, uczestniczyć w spotkaniach, podczas których dzieli się lagrowymi doświadczeniami, mądrością i spostrzeżeniami wyniesionymi z „piekła”. Odczuwa odpowiedzialność za to, co się wydarzyło, tłumaczy, że postrzega swoje doświadczenia jako szansę życiową: poznała, była w środku wydarzeń, zobaczyła je, poczuła na sobie. Wyznaje zasadę, że to, co widziała jako uczestnik i świadek, należy opisać i udokumentować własnymi słowami. Język, tekstowe odsłanianie oraz przesłanianie długotrwałych skutków traumy lub jej przepracowania odgrywają bowiem w zaświadczaniu o prawdzie istotną rolę. Intensywność przeżycia domaga się wyrażania w języku emocji konkretnego więźnia, dlatego właśnie, można przypuszczać, powstała ta książka, wywiad rzeka, publikacja ważna i w niektórych momentach zadziwiająca. Stanowi ona żywe studium emocjonalnego wymiaru ukrywania i ujawniania tożsamości, a także światopoglądu więźniów oraz laboratorium „zamrożenia i prób odzyskiwania emocji po traumie”.

Wątpliwości budzą niektóre sformułowania stosowane przez dziennikarza znanego na salonach jako agent Małgorzaty Rozenek-Majdan - Wiktora Krajewskiego, który twierdzi na przykład: „Próbuję ją wziąć [Alinę Dąbrowską - L.S.] pod włos. Szach-mat" (s. 14). Może razić jego nierozważny, dość swobodny i przez to niezręczny dobór słownictwa. W przypadku świadka historii trudno formułować stwierdzenie: „[...] jak z karabinu maszynowego wystrzeliłem, że ją podziwiam" (s. 10). To brzmi nieelegancko, prowokuje obrazy, które dla każdego byłego więźnia mogą być - jak sądzę - traumatyczne i przykre, przypominające

${ }^{6}$ Alina Dąbrowska przyznaje, że pierwszą próbę powrotu na teren byłego obozu podjęła $\mathrm{w}$ połowie lat 70 . Poczuła się wtedy jak w matni, jakby znalazła się w potrzasku swojej przeszłości, bała się, że oszaleje. Przeżywała koszmar na nowo. Wydarzenia z jej dawnego życia napawały ją tak wielkim przerażeniem, że nie była w stanie dojść dalej niż do samego napisu „Arbeit macht frei”. Drugą próbę podjęła, kiedy była już na emeryturze. Znajoma Niemka poprosiła, żeby towarzyszyła jej w Auschwitz. Zastanawiała się długo. Jak twierdzi, dopiero ta wizyta w obozie i spotkania z Niemcami sprawiły, że może wracać do przeszłości, nie czując przy tym bólu czy złości.

7 W podobny sposób pamięć o wojnie i Zagładzie umacniało wcześniej wiele autorek, m.in. Halina Birenbaum, która napisała, że: „[...] we wstrząsających zeznaniach świadków brakowało mi czegoś. Brakowało czegoś bardzo istotnego - atmosfery nieustającej grozy codziennego bytowania pośród wszystkich okropności wojny. Oddychałam tą grozą w ciągu niemal sześciu lat, w których każda godzina była wiecznością albo godziną poprzedzającą tę ostatnią. [...] Kiedy skończyłam pisanie, czułam się wspaniale: wywiązałam się! Właśnie to winna byłam zrobić, tego żądano ode mnie" (H. Birenbaum: Nadzieja umiera ostatnia. Warszawa 1988, s. 5-6).

${ }^{8}$ B. Przymuszała: Smugi Zagłady. Emocjonalne i konwencjonalne aspekty tekstów ofiar i ich dzieci. Poznań 2016, s. 340. 
wojnę, atak, zagrożenie. Krajewski, skracając dystans i próbując rozwiązać zagadkę, jaką do samego końca pozostaje dla niego Alina Dąbrowska, jednocześnie traktuje pisanie o życiu świadka historii - jak sam w wywiadach wyznaje - jako „odskocznię” od show-biznesu9. Trudno wyobrazić sobie bardziej odległe światy: celebrycki i lagrowy. Krajewski obcuje z kamerami i słyszy dźwięki migawek w aparatach fotograficznych, jego interlokutorka zaś wspomina: „Również Cyganie byli solą w oku Niemców. Gdy wypędzali ich z baraków i pędzili do gazu, oni już wiedzieli, co się z nimi stanie. Krzyki, jakie towarzyszyły tym sytuacjom, wwiercały się w mózg. Do dzisiaj je słyszę" (s. 209).

Podkreślmy: Alina Dąbrowska uczestniczyła w niezliczonej liczbie spotkań, wygłosiła setki prelekcji w szkołach i udzieliła wielu wywiadów, swoją postawą zaświadcza o „czasach pogardy”, zyskuje szacunek, uznanie, a w polskiej historii współczesnej - pozycję jednego z najbardziej otwartych i życzliwych świadków historii, który stoi na stanowisku, że „W miłości nic nie jest tylko czarne i nic nie jest tylko białe. Podobnie jest $\mathrm{z}$ tematem wojny. Trzeba pamiętać o całej gamie szarości pomiędzy" (s. 29).

To już nie tylko świadek walczący z praktykami fałszowania historii. Równolegle spełnia się jako żona, matka i babcia, kobieta realizująca swoje plany i marzenia, podążająca za swoim wewnętrznym kompasem, instynktem, co w życiu jest ważne, godne, przyzwoite i dobre.

Wiem, jak wygląda piekło... to książka, która ma walor ponadczasowy. Pokazuje Alinę Dąbrowską jako rozmówcę: wyrozumiałego, przychylnego, mającego wiele interesujących spraw do przekazania.

Ktoś może pomyśleć, że pomyliłam laudację z recenzją książki. Otóż nic bardziej mylnego. Ta rozmowa i jej rezultat w postaci publikacji to jakby immanentne cząstki Aliny Dąbrowskiej. Otrzymujemy precyzyjnie naszkicowany słowem portret bohaterki. To jakby lustrzane odbicie, jakaś jej ważna część. Czytając książkę, miałam nieodparte wrażenie, że słyszę głos Pani Aliny, jej śmiech, że siedzę naprzeciwko niej. Niezwykłe doświadczenie, jakiego byłam uczestnikiem podczas lektury wywiadu, niewątpliwie zawdzięczamy - mimo wszystko umiejętnemu prowadzeniu rozmowy przez Krajewskiego, który potrafił zawiesić głos, cierpliwie poczekać na moment, w którym interlokutorka poczuje się komfortowo i na tyle dobrze, by powrócić do traumatycznych wspomnień.

Najważniejszymi cechami, które charakteryzują Alinę Dąbrowską, są spokój i równowaga. To kobieta czerpiąca radość i satysfakcję z czynienia dobra oraz szukania w innych ludziach ich najszlachetniejszych rysów, odnajduje chwile szczęścia w dramatycznych historycznie czasach. Władysława Bartoszewskiego nazywa się budowniczym mostów, gdyż szukał on w ludziach tego, co ich zbliża i łączy, co pomaga pozbyć się urazów, których kiedyś doznali - tak można

${ }^{9}$ Por. Małgorzata Rozenek-Majdan jako pierwsza czyta moje ksiązki. Wiktor Krajewski wraca $z$ nowa publikacją. Dostępne w Internecie: https://plejada.pl/newsy/nowa-ksiazka-wiktora-kra jewskiego-agent-malgorzaty-rozenek-napisal-ksiazke/qp8ktql [data dostępu: 13.09.2019]. 
również nazwać bohaterkę recenzowanej książki. Dąbrowska działa i odczuwa bowiem w podobny sposób - w madame Cassis i jej córkach odnalazła za drutami kolczastymi bratnie dusze, sprawiające, że czuła się szczęśliwsza:

Podczas pracy jako sztubowa zaprzyjaźniłam się z jedną francuską Żydówką nazwiskiem Cassis. Przebywała w obozie z dwiema córkami: Lisette i Hugette. Moja znajomość z madame Cassis i jej córkami trwała ponad dwa miesiące. Szczęśliwie uratowały się z transportu, bo władze obozowe niszczyły Żydów, a je uznano za Francuzki. Mieszkałyśmy blisko siebie, rozmawiałyśmy po francusku i zaproponowałam, by jej córka uczyła mnie tego języka. Dzieliłam się z nimi tym, co dostawałam w paczkach, które do mnie jeszcze wtedy przychodziły. Dzieliłam się zwłaszcza chlebem. Młodsza córka miała czternaście lat i często chorowała. Starałam się ją odwiedzać, bo mogłam swobodnie poruszać się po obozie. Wtedy też uczyłam się francuskiego i czytałam. Nie pamiętam tytułów, ale czytałam książki, które do obozu przywieźli francuscy Żydzi. Po wojnie starałam się z nimi skontaktować. Kiedy byłam we Francji, dowiedziałam się, że madame Cassis i jej córki zmarły ${ }^{10}$.

Każdy żyje tylko raz, „nic dwa razy się nie zdarza i nie zdarzy”11, tego, co było, już nic nie zmieni. Trzeba umieć przemóc w sobie niechęć do ludzi, którzy wyrządzili nam krzywdę i przykrość. Zwłaszcza do tych. Dąbrowska nie twierdzi, że to łatwe, ale namawia, by szukać z nimi porozumienia.

Podobnie jak Bartoszewski Alina Dąbrowska podkreśla także, że w każdych warunkach warto być przyzwoitym. Warto wybrać życie godne.

Dąbrowska zawsze była optymistką i daje temu wyraz w wywiadzie. Współistniejące w niej patriotyzm, idealizm i romantyzm równoważą się z rozsądkiem, czemu towarzyszy pragmatyczne gospodarowanie tym, co się ma, unikanie czynienia zła, szukanie lepszego wyjścia. Kobieta uważa, że trzeba robić swoje. To wyjaśnia jej zgodę na powstanie omawianej książki. Nie można ulec pokusie poddawania się przeżyciom lagrowym i zakłamania dla własnego lepszego samopoczucia. Jak sama wyjaśnia: „Wszyscy chcieli przeżyć, więc musieli się dostosować do panujących reguł. Ale w obozie koncentracyjnym nigdy nie wiesz, co przedłuży twój żywot. Ja bym tak nie potrafiła, bo czułabym, że działam wbrew sobie. To już nawet nie chodziłoby o naginanie życiowych reguł, ale wyzbycie się ich do cna" (s. 163-164).

Wiktor Krajewski przyznaje już w początkowych partiach książki, że jest bezradny wobec życiorysu Aliny Dąbrowskiej. Próbuje ją zrozumieć, złamać... dopaśćc ${ }^{12}$.

10 „Oni szli do lasu, po prostu do lasu...”..., s. 370.

${ }^{11}$ W. Szymborska: Nic dwa razy. W: Taż: Wołanie do Yeti. Kraków 1957, s. 14.

12 Znamienny jest swego rodzaju monolog wewnętrzy Wiktora Krajewskiego: „Coś za szybko się zgodziła... Pani Alino, a gdzie w tym wszystkim jest haczyk? Oczywiście nie zadałem tego pytania na głos, ale zastanawiało mnie to zdecydowanie" (s. 12). 
Jest $\mathrm{w}$ rozumowaniu bohaterki publikacji i wolność, i oryginalność myśli. Są one efektem głębokiego namysłu. Wyjaśniają to dokładniej jej słowa: „Pobytu w obozie nie żałuję, bo wzbogaciło to moje życie. [...] Widziałam na własne oczy rzeczy, których nie opisują żadne książki. Nikomu nawet się nie śniło to, czego doświadczyłam. Dramat przeżywałam na początku, gdy przekroczyłam próg obozu. Później było już lepiej, ale poczucie zagrożenia towarzyszyło mi stale. Zawsze było obecne. Nie jestem aż taka skromna, żeby mówić, że nie miało to dla mnie znaczenia. Miało. I to ogromne" (s. 276). Czytelnik zauważa również, że postawa Dąbrowskiej wynika z zachowanego przez nią dystansu wobec spraw dotyczących znanego jej „piekła”. To najważniejsza bodaj cecha Dąbrowskiej: trzeźwość spojrzenia. Nigdy nie żyła złudzeniami. Nie lubi cierpiętnictwa, goryczy i obnoszenia się z ranami. Całkowicie są jej obce patos i męczeństwo.

Doskonale i intuicyjnie rozumie Dąbrowska tych, z którymi rozmawia i którym opowiada swoją historię życia. Nie jest naiwna, nie bierze każdego słowa czy gestu za dobrą monetę. Musi być do pewnego stopnia nieufna, ale to nie przeszkadza, by czytelnicy i rozmówca czuli, że bohaterka książki lubi rozmawiać, bez zbędnej wzniosłości i nachalnego dydaktyzmu dzieli się swoim doświadczeniem.

Alina Dąbrowska namawia kolejne pokolenia Polaków i Niemców do relacji opartych na zrozumieniu i szacunku, uczestniczy w dialogu intelektualnym i wymianie myśli, działa na rzecz pojednania narodów. Spotkania z nią ${ }^{13}$ niosą wielki ładunek edukacyjny, etyczny i moralny. Podobnie jak obcowanie z Dąbrowską na kartach książki. Jej odwaga cywilna jest kompasem zarówno dla młodszych, jak i starszych uczestników oraz konsumentów życia społecznego. Mimo wieku kobieta służy społeczeństwu. Jej obecność w mediach, na spotkaniach zależy od potrzeby, bywa bardziej widoczna przy rocznicach związanych $\mathrm{z}$ drugą wojną światową. Kiedy trzeba dać odważne świadectwo prawdy, Dąbrowska się nie waha. Jej głos ${ }^{14}$ jest wyjątkowo ważny, sugestywny, a można rzec, że i skuteczny.

Przeczytałam kiedyś, że dobra książka to taka, po lekturze której pozostaje niedosyt, a nie przesyt. Omawiana publikacja, która pozostawiła we mnie uczucie niezaspokojenia czytelniczego, do literatury lekkiej, łatwej i przyjemnej nie należy, choć w ostatnim czasie daje się zauważyć swoistą modę wśród celebrytów na publikowanie $\mathrm{w}$ mediach społecznościowych zdjęć wykonanych podczas

${ }^{13}$ Warto wymienić niektóre: „Przeżyliśmy Auschwitz” - spotkanie na Uniwersytecie Jagiellońskim 16 kwietnia 2015 r.; „Przeżyłam Auschwitz - spotkanie z Aliną Dąbrowską” w Klubie Seniora „Służewiak” w 2018 r.; w Fundacji Kluboteka Dojrzałego Człowieka spotkanie z cyklu „Kobiety niepodległości” 21 kwietnia 2018 r.; „Pani Dąbrowska niezwykłym świadkiem historii” 7 marca 2017 r. w LXIII LO im. Lajosa Kossutha; udział w 5. Zamojskim Festiwalu Filmowym „Spotkania z historią" 16-19 sierpnia 2017 r.; spotkanie z Zofią Dłubacz ze stowarzyszenia Maximilian-Kolbe-Werk w Niemczech w ramach projektu „Pamięć i upamiętnianie w dobie Web 2.0” 12 kwietnia $2011 \mathrm{r}$.

${ }_{14}$ Podczas uroczystości 73. rocznicy wyzwolenia KL Auschwitz-Birkenau Alina Dąbrowska przekonywała, że trzeba żyć bez nienawiści, we wzajemnym szacunku. Por. https://bielsko.gosc. $\mathrm{pl} /$ doc/4482414.Zrozumiec-bol-czlowieka [data dostępu: 13.09.2019]. 
lektury Wiem, jak wygląda piekło... Niepoślednią rolę w tym trendzie, który ma cechy działań promocyjnych, PR-owskich i biznesowych, odgrywa osoba Wiktora Krajewskiego ${ }^{15}$.

Dlaczego dobrze czyta się rozmowę Aliny Dąbrowskiej z Wiktorem Krajewskim? „Radość czytania”16 idzie tu w parze z głębokim namysłem nad kwestiami niezwykle istotnymi, nie tylko osiemdziesiąt lat temu, ale i współcześnie. Książka zastanawia, porusza, uwiera, nęka lub potwierdza prawdę, która jest immanentna, oczywista, „podskórna” - że zwątpienie w sens życia może przyjść w każdym momencie. „Najważniejsze jednak jest, aby w patowej sytuacji nie dać się ponieść chwili i złemu myśleniu, bo tak szybko jak ono się pojawia, może minąć. A jeżeli nasze złe myśli zaprowadzą nas do samej czeluści, z niej może nie być drogi powrotnej" (s. 151).

W niewielkim odstępie czasu czytałam wywiad z Aliną Dąbrowską, autobiografię Władysława Bartoszewskiego Warto być przyzwoitym. Teksty osobiste $i$ nieosobiste ${ }^{17}$ oraz biografię Wernera Besta ${ }^{18}$. Szczegóły życia wymienionych osób pozwalają zobaczyć, zrozumieć i oszacować cenę, jaką trzeba zapłacić w warunkach totalitaryzmu za przyzwoitość, „,enę wyboru godnego życia”. Best wybrał życie wygodne, podporządkował mu swoje talenty, inteligencję i czas. Dąbrowska i Bartoszewski wybrali życie godne.

Dąbrowską, Bartoszewskiego i Besta łączył czas, w którym przyszło im żyć, dzielił wybór sposobu postępowania. Rozmówczyni Krajewskiego uważa, że lepiej doznać krzywdy, niż ją komuś wyrządzić; nic tak nie wzmaga sił przeciwnika, jak sprawiony mu ból.

Podczas uroczystości nadania Władysławowi Bartoszewskiemu tytułu doktora honoris causa Uniwersytetu Opolskiego 10 marca 2008 roku padły słowa, że miał on w sobie coś z nowoczesnego proroka, który był namaszczony ideą chronienia ludzkości przed straszliwymi konsekwencjami, jakie ją czekają, jeśli nie usłucha przestróg. Tak samo jawi się w mojej wyobraźni Alina Dąbrowska, być może w mniejszej skali, ale jej profetyczna siła oddziaływania imponuje

${ }^{15}$ Projektantka Ewa Minge zamieściła na swoim profilu na portalu Instagram zdjęcie, które przedstawia ją leżącą na szpitalnym łóżku, na jej kolanach zaś widzimy książkę Wiem, jak wyglada piekło... Fotografia opatrzona została opisem: „Jak uprzyjemnić sobie czas w takiej sytuacji, kiedy życie zaskoczy? Najlepiej dobra literatura. Polecam, świetnie się czyta @wiktor. krajewski\#wiemjakwyglądapiekło \#mylife\#ewaminge \#evaminge" (https://www.instagram.com/ eva_minge/?hl=pl [data dostępu: 14.09.2019]).

${ }^{16}$ Nawiązuję do artykułu Ryszarda Koziołka zatytułowanego Zapomniane radości czytania („FA-art. Kwartalnik literacki” 1999, nr 3 (37), s. 14-19).

${ }^{17}$ W. Bartoszewski: Warto być przyzwoitym. Teksty osobiste i nieosobiste. Poznań 1990. Interesującym dopełnieniem autobiografii Władysława Bartoszewskiego jest publikacja M. Komara: Władysław Bartoszewski. Wywiad rzeka. Warszawa 2006.

18 Werner Best (1903-1989), niemiecki faszysta, ideolog nazizmu, tzw. morderca zza biurka, współpracownik Heinricha Himmlera. Zob. U. Herbert: Werner Best. Studium biograficzne o radykalizmie, światopoglądzie i rozsądku 1903-1989. Przeł. M. Kurkowska. Warszawa 2007. 
i wzbudza szacunek. Obóz koncentracyjny nazywa brutalnym światem, który ma nadzieję - „przestał istnieć raz na zawsze i już nigdy nie powróci” (s. 164).

LuCYNA SADZIKOWSKa - dr hab., profesor uczelni w Instytucie Literaturoznawstwa Uniwersytetu Śląskiego w Katowicach. Członek redakcji rocznika naukowego „Narracje o Zagładzie” i zespołu redakcyjnego czasopisma „Bibliotheca Nostra”. Z prof. dr hab. Krystyną Heską-Kwaśniewicz opracowała i wstępem opatrzyła tom Listy z Dachau. Gustaw Morcinek do siostry Teresy Morcinek (2016), który był nominowany do Nagród Historycznych „Polityki” w kategorii wydawnictw źródłowych. W 2017 roku wydała książkę Szukanie kluczy. O literaturze poobozowej Gustawa Morcinka, a w 2019 monografię Listy z lagrów $i$ więzień 1939-1945. Wybrane zagadnienia. Również w 2019 roku ukazała się publikacja Działalność poselska Gustawa Morcinka, czyli katalog ludzkiej biedy. Dokumenty w opracowaniu Krystyny Heskiej-Kwaśniewicz i Lucyny Sadzikowskiej. 